New York, 10-14 August 1970

\title{
Conf- $700810-44$
}

IABA-SH-146/23

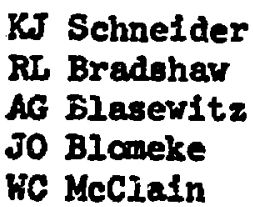

KJ Schneider

RI Bradihay

wit

HC MeCiain

\begin{abstract}
Battelle-Northwest, Richland Wanhington
Oak Ridge National Laboratory, Ouk Ridge, Tennessee Battelle-Northwest, Richland Washington

Oak Ridge National Laboratory, Oak Ridge, Tennessee Oak Rldge Hational Laboratory, Oak RIdge, Tennessee
\end{abstract}

Based on Work Performed ror the United States Atoraic Energy Conmission

LEGAL NOTICE

This report was prepared as an account of work sponeored by the United States Government. Nefther the United States nor the United States Atomic Energy Commission, nor any of their employees, nor any of their contractors, subcontractors, or their employees, makes any warranty, express or implied, or ascumes any lorel linbility or responsibility for the accuracy, complatenes or usefulness of any information, apparatus, product or process disclosed, or represents that its use would not infinge privately owned rights. 


\begin{abstract}
Solidification of highly radianctive 1 lquil wastes fron reprosessing of spent nuclear fuels will soon be required in the USA for additional improvement in safety during interim storage, during transportation to flnal disposal, and during finel disposal at a Federal repository. During the past 15 years, major research and development has been carried out to develop four basic processes for converting the high ievel liquid wastea to encapsulated solids. These processes are: spray solidification, pot calcinetion, phosphete glass solidiflcation, and Iluidized bed calcination. All processes are beling demonstrated on an engineering-scale with radioactive wastes. In all four processes, the waste is heated to $400{ }^{\circ} \mathrm{C}$ to $1200^{\circ} \mathrm{C}$ to drive off essentially all of the volatile constituents. leaving a solid or a melt that will cool tó a solld.

Disposel of these radioactive wastes requires fsolation fran the biological environjent for hundreds of thousands of years. The longevity of the hazard Irplies that the disposal systein should be capable of providing this isolation without survelliance. After considerable study, natural salt deposits were concluded to be the most promising disposal locations in the USA for meeting these criterio. A concept for a faclilty to aispose of containers of solidified highly radioactire vaste in a salt mine has been investigated in an experiment in a salt mine. The overall disposal concept, as vell as equipment requirements and handling techniques, were demonstrated.
\end{abstract}

The US-AFC has proposed that all solidifled highly radioactive waste from nuclear power fuels be shipped to Federally owned repositories. Studies are currently in progress on the detailed design and cost estimates fo: such a first demonstration disposal facility to be located in a salt mine in the central area of the USA.

The cost of high level waste management involving solidification in combinations with interim liquid storage, interim solid storage, transportation to final disposal, and disposal in a salt mine has been estimated to be about 35 to $50 \mathrm{mlls} / \mathrm{Ml}$ hre; or only slightly higher than the cost range for perpetusl liquid storage. 


\section{INTRODUCTION}

The conversion of high-level liquid wastes to solids as a pretreatment for storage is being developed in nearly all countries with significant near-future nuclear energy. Solidification is being developed so widely because it is the only reasonably attainable technique for achieving a substantial increase in the safety associated with the storting and disposal of the high-level waste from the nuclear power industry.

Storage of high-level wastes as solids will provide significantly more safety than storage as liquids because solid wastes are:

- Imobize,

- Less soluble in water,

- Considerably smaller in volume, and

- Nore rugged physically than those stored in liquids.

After solidification, the wastes nust be stored virtually forever under table, controlled conditions. Guldelines, for such storage in the USA have been proposed in the Federal Refister. [1] These guidelines propose that all high-level wastes must be solldifled within 5 years after the source tuel has been reprocessed, and the solidified waste must pe shipped to a Federal repository within 10 . years after fuel reprocessing. 
The origin and disposition of high-level rastes are shom in Figure 1. Here, one tonns of nuclear fuel is used in a nuclear reactor to generate electricity. The partially spent fuel is then removed from the reactor, aged for a few months, then processed for recovery of usable naterials which are refrubicated into new ruel elements. About $99.9 \%$ of the nonvolatile fission products are contained in the aqueous high-level radioactive waste effluent from the reprocessing step. Currentiy, these aqueous wastes are stored in underground tanks which are susceptible to fallure and must be replaced every 15 to 40 years. With solidification, the wastes would then be deposited in locations such as in salt caverns.

Host spent fuel reprocessing is done by the Purex solvent extraction prosess. The resultant high-level wastes are primarily aqueous solutione of nitrate anits, depending upon the reogents added to the solutions during reprocessing. 
is a result of research and development conducted in the past 15 rears, four processes for solialfication of $\mathrm{h}$ igh-level wastes have been dereloped in the USA to the point of radioective demonstrations on an engineering caie. The processes are pot calcination, spray solldification, phosphate glass solidification, and fluidized bed calcination.

In all four processes, heat is applied to raise the ternperature or the vaste to 400 to $1200^{\circ} \mathrm{C}$. At these temperatures, essentially all of the rolatile constituents (primarily water and nitrates) are driven off. learing a calcined solld or melt that will cool to a solld.

Solldiflcetion processes which form melts require oignificant chemical modiflcation of the chemical composition of the waste. Generaliy, at least 70 iole 7 of inert chemicals are required to incorporate the fision products into materials that are meltable at reasonably low temperatures, or 1 ess than about $1000^{\circ} \mathrm{C}$. Melt have been developed in which the pof celtmaking fluxes are phosphates $\{3,4,5]$ silicates, $\{6,7]$ or borates, $\{8\}$ or some coubination of these. $\{9,10,11]$ In most cyses, potentially vorkable chemical composition renges have been defined. $[12]$

\section{POT CAICIHATION}

Pot cafcination, which was intilally developed at the Cak Aidge National Laboratory, $[12,13]$ is a betch process that has been developed to a state of readiness for commerclal use. It is presently belng demonstrated with rull-level radionctivity by Battelle-Northwest in the AEC's Waste SolldiIication Engineering Prototype, or WSEP. $[14,15]$ The process is simple and is adaptable to a vide variety of feed compositions.

In pot calcination, shown in Figure $2 a, 15 q u i d$ waste is added to - pot that is heated in a mitiple-zone heating and cooling furnace. The principal processing ressel, the stainless steel pot, is also the final container for the solidifled waste. The waste is concentrated at a constant volune until scale (salt cake) forms on the walls or the pot. As calcination continues, the scale grows in thickness and reduces the capacity for boiling the remaining sludge, and therefore the feed rate mast be reduced proportionately. When the feed rate is reduced to an "unprofitable" rate (about 5 liters/hr) the feed is shut off. At this point, the scale has erown inward from the pot wall and upward frow the bottom to fill the pot, except for a thin-cone-shaped liquid-containing rold in the upfer 2 to 3 reet of the salt cake. Heating is continued until the remeining Ifquid is bolled to drymess and ail of the waste in the pot has been caicined and has reached the temperature of 850 to $900^{\circ} \mathrm{C}$. The pot is then cooled in the furnace, removed, sealed, and taken to storage. 
Spray solfdification, which was developed by Battelle-Northwest, [8] is a continuous process that is approaching readiness for commercial use. It is currently being demonstrated by Battelle-Nortbwest on a pllot plant scale with full level radioactivity in the WSEP. [16] It is a continuous process with low hold-up volumes, it is adaptable to a moderately wide variety of feed compositions, and it produces a variety of good quality solids.

In the spray calciner, shown in Flgure 2b, liquid waste (which sontains some or all of the melt-making additives) is fed through a pnewnatic atomizing nozzle into the top of a heated cylindrfcal tower. The atonized waste is sequentialiy evaporated, drjed, and calcined to a powder as it falls into a continuous melter below the calciner where it is melted at temperaturea of 800 to $120{ }^{\circ} \mathrm{C}$. Process gases from calcination flow into the adjacent lilter chamber, carrying much of the calciner powder. The powder collects on the porous metal filters as the gas passes through. The poider is periodically blown off the filters and into the welter by sudden pulses of high-pressure steam or air directed backward through the filters by small noziles. The molten calcine flows through an orerflow weir or a rreeze valve into the receiver-storage pot below. After the pot is fllled, it is cooled in the furnace, sealed, and taken to storage. The pot for receiving the moIten waste nay be made of alld steel if the pot is kept below about $700^{\circ} \mathrm{C}$.

The flowsheets most used for spray solidification at Battelle-Horthrest produce cermic, orthophosphate solids or alkall metals, and iron. Calcium is added to retain sulfates when present. [15] Alternative flowsheets which produce borosilicate, semi-glassy solids haye been demonstrated recentIy. Some of these flowsheets have been demonztrated with a scherie which eliminates the selter and performs final melting in stainless steel conteiner. [17]

\section{PHOSPHATE GLASS SOLIDIFICATION}

Phosphate glass solidification is a continuous process which has been extensively developed at Brookhaven fiptonal Leboratory and is epproaching readiness for comercial use. [18] It has been demonstrated on pilot plant scale with rull-Jevel radioactivity in the WSEP. [ig\} It is a continuous process that produces good quality glass product.

In phosphate glass solldification, shom in Figure 2c, liquid vaste which contains all of the melt-making additives is first fed to the eraporator where it is concentrated and denitrated by factors of 2 to 10 to a thick, syrupy, aqueous phosphate slurry. The slurry in then fed to the continuous melter where final volatilization of the vater, nitrated, and other rolatile constituents is accomplished, and the aterial is 
heated to 1000 to $1200^{\circ} \mathrm{C}$ to form a molten glass. The molten glass flows through an overflow veir or freeze valve into the receiver-storage pot below. After the pot is rilled, it is cooled in the rurnace, sealed, and taken to storage.

The pot for recelving the molten glass is similar to that for the eprar solidification procesi.

The chemical adjustmerst sequired for the phosphate glass process consist malnly of adding phosphoric acid to the feed to obtain a metaphosphate melt, with the oxides of the alkall metals at least half of those of the total metal oxides in the melt.

\section{FLUIDIZED BED CALCINATION}

The flufdized bed solidf ication process is a continuous process that has been extensively developed for use with aluminum nitrate and zirconium-fluoride-aluminum nitrate vastes. Development of rluifized bed solfdification was inftiated at Argonne Hational iaboratory, [20] and has been extensively demonstrated by the Idaho Nuclear Corporation. [21] The process, has been fully demonstrated with moderate radioactivity levels In production-scale equipment sipce 1963 and is ready for commercial epplication for these wastes. [21] Development with the more uneriendly Purex vastes hes been limited. The process provides a relatively high capacity for given equipment size.

In fluidized bed solidification, shown in Fiture 2d, the liquid waste is injected through pneumatic atomizing nouzles into the side of a heated ( 400 to $600{ }^{\circ} \mathrm{C}$ ) bed of Eranular solids which is continuously fluidized by gas sparging upward through the fluidized bed reactor. Contact of the vaste uith the hot, granular bed results in evaporation and calcination of the feed as coatings of the bed particles. The calcine that is entrained with the caiciner off-gases is removed from the gas strean by cyclone separators or. filters, then returned to the mainstream of particles. The nainstream of particles is continuously remored from the reactor and transported to storage tanks. 
The main incentive for converting high-level radioactive liquid wastes to solids is for lmproved 1solation and safety during the millenia of time that the material must be contained. The most important concern Is during the first 10 years after solidification when the heat removal problems, temperature, radioactivity, and rate of temperature change are the ereatest, and during transportation to the long-term disposal site.

To provide this increased safety, the desired characteristics of solidified wastes with primary importance are:

- Good thermel conductivity.

- Lou Leachablility,

- Good chomical stability and radiation reslstance,

- Hechanical ruggedness,

- Noncorrosiveness to container,

- Minimum volume,

- Minimun cost.

The net effect of a high thermal conductivity is to increase the amount of allowable hent stored in a pot of a given size. This characteristic permits reduction of the amount of time that liquid waste must be stored before solfdification and permits decreases in the volume of solfdified wastes. Iow leachability is desired to minimize the amount of radioactivity in water that vould reach animal life, in the even tacts a breached container of solidified wastes. Solfdified wastes provide significantly improved leachability compared to liquid vastes. The reasons for the desirahility of the other Iisted characteristics are obvious.

Table 1 shows the typleal charactertstics of solidified high lerel vastes from Purex wastes.

The solidified waste from pot calcination is a mixture of oxide scale of the metallic constituents in the original liquid waste. The solid is a porous, friable calcine with a low thermal conductivity and a relattrely high solubility in arqueous solutions.

The spray solidified vaste is a monolithic solid forwed after cooling the melt. The solid is a tough, microcrystelline, rock-like material with good thermal conductivity and a moderately low solubility.

The phosphate glass solid is a monolithic, moderately brittle glass formed after cooling the melt. The glass has a fairly good thermal conduetivity and lor solubility in aqueous solutions.

The tluidized bed calcine is granular with mean particle diameter of about 500 microns. The granules may be composed of crystals or amarphous solids. The granules are generally spherical in shape and are moderately soft and triable. Their thermal conductivity is relatively low. 
TABLS 1. Characteristics of Solidifled Bigh-Ievel Purex Wastes

Form

Description

Mole $D$ Fission Product Oxides

Buik Density, B/ml

Therwal Conductivity, Btu/(hr)(ft) $\left({ }^{\circ} \mathrm{F}\right)$

Meximum Heat, W/Ilter solid (a)

Leachsbility in Cold Water, $8 / \mathrm{cm}^{2}$-day

Hardness

Fesability

Residual Nitrate, wt:

volume, Ilters/1000 Mwd

Naximum Stable Teriperature, ${ }^{\circ} \mathrm{C}$

Containex Material

Pot Calcine
Calcine cake
Scale
Up to 80
1.1 to 1.5
0.15 to 0.25
85
1.0 to $]^{-1}$
soft
Crumbly
$\leq 0.05$
1 to 2.5
2900

ss

\begin{tabular}{|c|c|c|}
\hline Spray NeIt & $\begin{array}{c}\text { Phosphate } \\
\text { Glass }\end{array}$ & Flusd Bed \\
\hline Konolithte & Monolithic & Granular \\
\hline Microerystalline & Glass & Amorphous \\
\hline Up to 20 & Up to 25 & up to 50 \\
\hline 2.7 to $\mathrm{s} .3$ & 2.7 to 3.0 & .1 .0 to 1.7 \\
\hline 0.5 to 2.0 & 0.4 to 0.8 & 0.10 to 0.25 \\
\hline $\begin{array}{l}205 \\
10^{-3} \text { to } 20^{-6}\end{array}$ & $\begin{array}{l}290 \\
10^{-4} \text { to } 10^{-7}\end{array}$ & $\begin{array}{l}70 \\
1.0 \text { to } 10^{-1}\end{array}$ \\
\hline Hard & Very Hard & Moderate \\
\hline Tough & Brittle & Moderate \\
\hline$\leq 0.005$ & $\leq 0.0005$ & $\leq 4.0$ \\
\hline 1.2 .503 & 2.5 to 5 & 1.5 to 5 \\
\hline $\begin{array}{l}\text { Phase Separation } \\
\text { at } ی 000 \text {. }\end{array}$ & $\begin{array}{l}\text { Devitrdefles at } \\
2500\end{array}$ & 1600 \\
\hline MS or SS & MS or ss & MS or SS \\
\hline
\end{tabular}

(a) Approximate values for storage in air in 8-inch diameter cylindrical pots to maintein pot centerine temperatures less than $900^{\circ} \mathrm{C}$ and pot vall temperatures 1058 then $425^{\circ} \mathrm{C}$. Average $\mathrm{k}$ values were used. 
A photograph of samples of the four types of solidified vastes is presented in Figure 3. 
The pot, spray, and phosphate glass processes have been demonstrated since 1966 for the Atomic Enerey Comission at processing rates of 10 to 20 liters/hr of high level liguid waste, or waste from about 1 tonne/day or auclear ruel. Demonstrations will be completed later in 1970. The Iuldized bed process has been dexonstrated since 1963 for the Atomic Bnergy Comission thigh rates of 300 itters/hr of intermediate level vastes. Scale-up of all processes for Purex rastes beyond about 1 tonne/day equivalent fuel w111 require some additional nonradioactive developnent.

In 1971, the one tonne/day Midwest Fuel hecovery Plant near Morris, Illinols will be started up, and will convert Its high level waste to granular solids by fluidized bed calcination: Within the next two years, the Atomic Energy Comission's waste solidification development program of currently-known concepts will be completed and reported. Efrects of cevere temperature and radiation on the properties of the solidified waste products vill have been rueasured and evaluated. Evaluations will provide rellarle bases for decisions on the management of high-level wastes, as vell as for the desiri, operation, and safety of waste solidification plants. 


\section{FIMAL DISPOSAL IN SAET}

An ldeal scheme for disposal of highly radioactive wastes is considered to be one which provides for complete isolation and absence of interaction of the waste from man's biosphere for time pericds on the order of several hundred thousand years with no operation, maintenange, or survelllance required after disposal, and at economical cost. [2]

Storage of wastes as liquids in near-surface tanks has been successful means for containing the radioactive wastes to date. Such atorage 15 considered to be temporary oniy, because the waste is contained in a mobile form within our biosphere, the tanks must be periodically replaced due to corrosion failure, and continual operation and survelilance are required.

Other disposal alternatives which have been investigated in the Researeh and Development programs sponsored by the US Atomic Energy Commission are: (1) disposal as solids in surface or near-surface vaults; 22 (2) disposki as liquids or slurries in caverns in deep geologic formatifons; [23] (3) disposal as solids in caverns in deep ceologic formations. [24]

Disposal of vastes as solids in surface or near-surface raults on comercial reprocessing plant sites appears acceptable for interim storage. However, far the very long term, surface disposal of solids is considered better than disposal in selected deep geologic formations because of the requirement of continued surveillance.

Safety considerations militate against the bulk shipment of high-level waste liquids or slurrles. Consequently, storage of these wastes in deep geologic formations would require suitable geohydrologic conditions at the fuel reprocessing site, thus limiting the number and location of aut table reprocessing plant sites. Disposal of high level waste liquids or slurrfes in deep underground formations has not been evaluated economically or technically for power react or fuel reprocessing waste. However, the need to expend millions of dollars to detexmine whether any selected geologic formation is positively suitable for such an application would appear to Iimit this concept. While this concept cannot, at the present time, be conclusively eliminated either on the basis of safety or economics, it Is not expected to be an important concept in the nuelear power econcuy.

Disposel of high-level waste solids in selected deep geologic formations appears acceptable from both the safety and economic atendpoints. The initial stimulus for this part of the AEC effluent control ReD program commenced in September 1955, when, at the request of the Atomic Ener $6 y$ Coumission, a committee of geologists and geophysicists was established by the National Acaderny of Sciences-National Research Councli to study the posgibilities of disposing of high-level radioactive waste materials on land, and to indicate what research was needed to determine the feasibility. 
The results of this Committee's study and their recommendations can be summarized as follows:
"Disposa? In salt is the most promising method for the near future. Researsh should be pushed immediately on the etructural problem of atability vs size of cavities at a given depth; on the thermal problem - getting rid of the heat or keeping it down to acceptable levels--."."

In response to the NAS subgestion, a major part of the AEC ground disposal R\&D program in recent years has been directed toward determining the sultablifty of using underground salt formations for the disposel of highlevel solfdified radioactive waste. The results of these studies, performed largely of the Oad Ridge National Laboratory, support the premise that bedded sali formations are good locations for disposal of these wastes.

Bedded salt formations are unique in that they are practically always dry, they have not been associated with ground water for millions of years, and they should retain their integrity ior milions of additional years. Because of the plasticity of salt, fractures seal or close rapidy, thereby forming on impervious container for entrapped materials. Salt beds are generally located in areas of low seismic activity and widely separated from floring aquifers as evidenced by the very existence of such deposits. Salt has a considerable compressive strength which is similar to that of concrete, and good thermal conductivity and heat capacity. Large spaces may be mined out, and, even at depths of 1000 feet, more than half of the salt area may be removed with only sight deformation of the support pillare.

Salt formations which are desirable for disposal of radioactive wastes should be at least 200 ft thick, and should be within 2000 ft of the surface. The locations of major salt deposits in the United States which meet these criteria are shown in figure 4 as four cross-hatched areas (two in Michigan, one in New York, and the one in Kansas). Other areas are not necessarily ruled out for future waste repositories; but those shown are more than adequate. For example, the area in central Kansas alone is about 10,000 square miles.

Salt mine space required for all the high level waste from reprocessing of power reactor fuels in the US by the year 2000 , aged 10 years to the year 2010 before disposal, is approximately 2500 acres, based on recent nuclear power predictions by the Atomic Enerey Comaission.[26] By the year 2070 this need will have increased to 50 to 100 square miles, which is still a small portion of the thousands of square miles available which are sulteble for waste disposal.

\section{CONCEPT FOR DISPOSAL IN A SALT MINE}

The high-activity, fuel reprocessing wastes which are solidified by one of the severat processes discussed previously would be sealed in containers of about 6 to $24 \mathrm{in}$. In diameter, and up to about $10 \mathrm{ft}$ long. 
After possibze interim storage at the fuel reprocessing site, the containers yould be shipped to the salt mine which had been previousiy developed in nearly conventional fashion. At the mine, the waste containers rould be unloaded in a hot cell located at the top of a special shaft extending to the mine level. After Inspection and any necessary decontanination or recanning, the containers would be lowered, one at time, into a shielded inderground transporter positioned under the waste shaft.

Once a vaste can is in the underground transporter, it rould be moved to the current disposal room and deposited into a hole drilled in the floor. The hole rould then be backfilled with $G$ to 8 feet of crushed salt:

Figure 5 shows the layout of one sector of a typical mine designed especially for waste disposal. The mine space would be developed so that rentilation air serving concurrent excevistion and disposal operations are completely isolated and that personnel never enter a ventilation alr stream after it has passed a filled disposal room.

The holes in the flsor would be spaced to dissipate the fission product decay heat without exceeding either the allowable waste temperature or the specified salt temperature of $200{ }^{\circ} \mathrm{C}$. After all the holes in a given rocm have been filled, the room itself would be beckfilled vith crushed salt obtained from the excavation operations. The design of the entire operation, including the sizes of the disposal rooms and the support p13lers, would be such that plastic flow, accelerated by the elevated temperatures, vil cause a consolidation and recrystalizination of the salt thus returning the salt bed to very nearly its undistuxbed state after a fer decades.

\section{PROJECP SALT YAULT}

A Pleld-scalc test of this aisposial concept yas undertaken in an inactive salt mine at Lyons, Kansas. $[27,28,29,30]$ The principal objectives were to show the feasfbility and safety of both the concept and the watehanding equipment, and to determine the effects of heat and radiation on In-situ salt which would permit detailed desfen of an sctual disposal faclilty. In this experiment, which wes carried out from Noverber 1965 to January 1968, irradieted fuel assemblies from the Engineering Test Reactor at Idaho Falls were used to provide sources of Intense radionctivity, while electrical heaters supplemented the decay heat generated by the fuel. The demonstration duplicated proposed actual disposal operations as nearly as practical.

The objectives of the experiment were met. There vere no detrimentel effects of heat and radiation on the sialt bed, and enough information vas obtalned to permit desien of a disposal facility. More than h miliion curles of radioactivity in 42 irradiated Engineering Test Reactor Tuel assemblies were handled in 21 separate contalners without the aid of surface hot cells (although hot cells would be required in an acturl facility). 
As anticipated from prior laboratory experiments, the structural and chemical properties of salt were not signif'icantly altered by the intense radiation fields. Radiolytic production of chlorine gas did not occur at detestable rates. The siructural behavior of the salt was affected by the elevated temperatures and thermal stresses surrounding the heat sources, and it wes demonstrated that the effects (primarily due to increased creep rates) can be predicted and handied by standard inining techniques.

Smal, brine-filled cavities in the salt, which constituted about i/2 volume of the salt were found to migrate toward the heat sources and into the holes containing the sources. In an actual disposal facility, this influx of molsture would amount to a maximum of 0.2 to 1 liter per year per hole, and could lead to stress-corrosion-cracking of portions of tainiess steel waste contalners, and fallure of the containers in as short a time as a few months. Even if stainless steel waste containers do fall due to stress corrosion cracking, no problems are anticipated in the disposal operation because the holes and rooms would be backfilled before the containers failed and ventllation of the various roons would be controlled. If the containers are of mild steel, only generalized rusting is expected, and container integrity should be maintained for a period of years.

\section{OURREAT STATUS OF SALT DISPOSAL}

Folloring the experimental studies, a preliminary study was made of - conceptuai salt mine facility which would handle the entire output of high level yaste from us power reactor fuels until about the end of the century. $[31]$ The overali conclusions from this study vere that disposal In salt appears to be a practical, relatively low-cost scheme, and adequate bedded salt deposits exist in the United States for application of the disposal scheme. Currently, a more detailed design and cost study is being made at ORWL for a combined demonstration facility to be operable In the ald-seventies to handle both the solidified power reactor fuel vastes, as vell ws the essentially non-heat-generating wastes which contain swall quantities of long-lived alpha emitters. 


\section{ESTIMATED COSTS}

A number of cost estinate studies have been made by Blomeke and coworkers at ORWL. These studies have investigated the total costs of man. ring high level wastes, which incluỏe interim liquid storage, conversion to solids. by pot calcination, interim solids storage at the fuel reprocessing plant, transportation of solias to a salt mine, and handling and burial of the solid waste in a salt mine. A summary of these cost estimates is presented in Tabie 2. For the cases examined, costs for total waste management are estimated to be in the range or 35 to $50 \mathrm{mills} / \mathrm{MN} \mathrm{hre}$, or $\$ 9000$ to $\$ 12,000$ per metrie ton of ruel pro cessed. These costs represent approximately $1 \%$ of the total cost of nuclear power, and approximately $20 \%$ of the total cost of reprocessing spent nuclear fuels. Comparable costs for perpetual storage as liquids vary from 30 to $35 \mathrm{mills} / \mathrm{MW} \mathrm{hr}_{\mathrm{e}}$, or near the lower end of the range for storage as solids. 
TABLE 2

COST RANGE FOR MANAGEIENP OF HIOR-LBVEL HASTES FROY LWR FUELS $(a)$

Operation

Interin Inquid Storage Irom 1 to 5 Years

Pot Calcination in 6 to 12-in. Dianeter Pots $(b)$.

Interim Sollds Storage from I to 10 Years

Shipwent of Sollds 2000 Miles

Burial in Salt after Aging 1 to 10 Years

Totals for Specific Schemes
Cost Range,

ailis/AH hre

14 to 22

4 to 3.8

2 to 10

2 to 3

3 to 11

37 to 45

(a) 33,000 MWd/Mr expasure

(b) 1 cubic toot of solids/10,000 $\mathrm{wWd}_{\text {th }}$ 
Solidification represents the only practical and reascnably attainable technique for achieving a shbstantial increase in the cafety associated with the storing and disposal of the high level waste from the nuclear porer industry. The use of this technique is expected to soon becoue a policy of the US Atomic Enerey Commision, wherein the solidification of hibhly radioactive liquid wastes will be required before shipment to a long-term federal disposal site.

Major AEC-8ponsored research and development on processes for converting the high-level Iiquid wastes to encapsulated solidis is nearly completed. Fron these studies, four basic solidification processes which are essentially ready for commercial application have erolved.

After considerable engineerfing and experimental study, nined caverns in natural salt deposits were concluded to be the nost promising locations to provide the isolation required for hundred of thousands of years. Studies are current Iy being made on the details of a Federal demonstration disposal facility in a salt mine in central USA.

The cost of $h I g h-l e v e l$ waste management involving solidification in combinations with interin Ifquid storage, Intierim solid storage, and transportation to final disposal at a salt mine has been estimated to be in the range of 37 to $50 \mathrm{mills} / \mathrm{MH}$ hre, or only slightly higher than the cost range for perpetual liquid storage. 
1. U. S. Federa? Register, Mitle 10; Part 50, "Licensing of product and utilixation racjlities," 34105 (1969) 8712.

2. BETTER, ท. G., MC VEY, ห., BARTLETT, C. B., MATTERN, K. L., REGAH, H. F., The AEC's posicior on radiactive waste management, Nuclear Ilews (November 2969 ).

3. NHDEL, J. E., KEY, G., HC EIROY, J. L., "Deslgn verification testing of waste solidification processes," USAEC Rep. COKF-660208 (Richland, Washington Symposium 1966).

4. BAPTON, G. E., Solidification of High-Hevel Wastes, Part IV, Fhosphate Nelis for Fixation of Redionctive Residues from Purex Type Wastes, Three to Flfty Percent Fission Prokuct Oxides, USAEC Rep. BAWL-60 (2965).

5. BARrOH, G. B., Solidification of High-Level Wastes, Part V, Factorial Study of the Effect of Varying the Concentration of the Components of Purex Type Hoste on the Properties of Phosphate Solids, USAEC Rep. BRWL-544 (1968).

6. JOHWSOA, K. B., GROVER, J. R., HARDWICK, W. H., Hork in the Unfted Kingdon on fixation of highly radioactive wastes in glass, $A / C O M F .28$ (Geneva Symposium 1964) 188.

T. BOWNIAUD, $\bar{n}$., "Survey of the studies conducted in France on the solldification of coincentrated fission products," USAEC Rep. CONF-660208 (Richland Washington Symposiun 1966).

8. KASER, J. D., MOORE, J. D., "The development of a spray-calciner-melter," USAEC Rep. CONtי-66020B (Richland, Washington Symposium 1966).

9. BARION, G. B., Solidification of High Level Wastes, Part VI, Mixed Phosphate, Borate, Silicate Mel+s for Fixation of Purex Type Wastes, USABC Rer. INIT-373 (1957).

20. MHEDL, J. B., "Prepartion of melts from solidified waste," Quarterly Progress Report, Fesfarch and Development Activities, Fixation of Radiosctive Residues (PLATT, A. K., Bd.) USAEC Rep. BNHL-T6 (1965).

11. CLARK, W. E., GODBEE, H. H., "Fixation of simulated highly radiosctive vastes in Elassy solids (Viema Synuosium 1962).

12. SCHEIDER, K. j., Ed., Waste Solidification Program, Volume 1, Technology for the Pot, Spriy, and Phosphate Glass Solidifieation Processes, USABC Rep. BWWL-1073 (1969). 
13. CLARK, W. E., SUDDATh, J. C., HANChER, C. W., BLANCO, R. E., GODBEE, H. H. HOLMES, J. M., PITZGERALD, C. L., Development of Processes for Solfiffleation of High Level Redioactive Hastes: Sumary for Pot Calcination and Rising Level Glass Processes, USAEC Rep. ORIL-Mh-1584 (1966).

14. MC ELROY, J. I., COOLEY, C. K., DE MIER, W. V., MENDEL, J. E., BLOMEKE, J. 0., SUDDATH, J. I., Pot Calcination Performance During First Radioactlve Tests in Waste Solialfication Engineexing Prototypes: Waste Solidification Progran, Volume 4, USAEC Rep. BNWL-814 (1968).

15. BLASEWITZ, A. G., MENDEL, J. E., SCHNEIDER, K. J., THOLPSOA, R. J., Interim Status Repont on the Waste Solidificaifion Demonstration Progran, USAEC Rep. BirkL-1083 (1969).

16. BOND, W. R., HARTLEY, J. N., MCNDEL, J. E., MC ELFOY, J. I., SCHTEIDER, K. I., SCHWA, M. R., Waste Solidification Program, Polume 6, Spray Solidification Performance During First Radioactive Tests in the Waste Solidification Engineering Prototypes, USAEC Rep. Burt-1391 (1970).

17. BOKD, . R., NENDSL, J. E., Personal communcation with SCHREIDER, K. J. (1970).

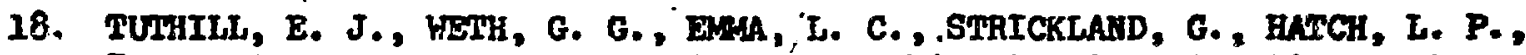
Phosphaie glass process for disposal of high level radioactive vastes, IKEC Process Design and Development 6 (1967).

19. MC ELROY, J. L., HARPLEY, J. H., SCHAEIDER, K. J., (BMW), DRAGER, R. F. (BuL), Waste Solidification Program Volume 5, Phosphate Glass Solldification Performence During the First Radioactive Tests in the Waste Solidification Engineering Prototypes, USAEC Rep. BurL-1185 (1970).

20. LOZDTHG, J. W., CARLS, E. L., AlASTASIA, L. J., JOKKE, A. A., The Pluta Bed Calcination of Radioactive Haste, USAEC Rep. AvL-6322 (1961).

21. COMMANDER, R. E., LOHSE, G. E., BLACK, D. E., COOPBR, E. D., Operation of the Haste Calcining Facility with Highly Radioactire Aqueoub Waste, USARC Rep. ID0-14662 (1966).

22. PEEXiA, J. J., et. al, Conparative Costs for Final Disposal of Radioactive Solids in Concrete Vaults, Granite, and Salt Formaticas, USABC Rep. ORNL-TM-664 (1963).

23. BELTER, 11. C., Ground Disposal of Radioactive Waste in as Bxpanding Nuclear Power Industry, Annual Meeting of American Institute or Mining, Metallurgical, and Petroleum Engineers (Washington, D. C. 1969).

24. REGAN, H. H., EA., Proceedings of the Symposium on the Solfaifleation and Long-Term Storage of Highly Radiontive Wastes, USABC Rep. C0N1-560208 (Richland, Washington Symposium 1966). 
25. Comittee on Weste Disfosal of the Division of Earth Sciences, Disposal of Hadioective Wastes on Land (National Academy of Sciences-Hatiorial Research Council Publication 519) (1957).

26. BAPILELT, C. B., Personel comunication with BLOKEKE, J. 0. (1970).

27. BRADSILA,, R. I., et. al., Disposil of high activity porer reactor wastes in salt mines: a concept and field scale demonstration, Fuclear Structural Engineering 2 (2965) 438-446.

28. BEOGLY, W. J., Jr., et. al., Project Salt Vault: demonstration disposal of high-level radioactive solids in Lyons, Kansas, salt mine, Health Physics 1? (1966) 4?7-424.

29. MC CLAIH, H. C., BRADSHAW, R. L., EHPSOH, F. M., Disposal of highlevel solidified wastes in salt mines, Disposal of Radioactive Wastes Into the Ground (IARA, Vienna 1967) 549-562.

30. BRADSHAH, R. L., EMPSON, F. M., MC CLATH, H. C., HOUSER, B. L., Results of a demonstration and other studies of the disposal of highlerel solfdified radioactive wastes in salt mine, Health Phystes 18 (1970) 63-67.

31. BRADSHAH, R. L., MC CLATH, W. C., BLOLEKL, J. O., Unpublished data fran Oak Ridge National Laboratory (1969).

32. Oak Ridge Niational Laboratory Staff, et. 81., Considerations Related to the Siting of Fuel Reprocessing Plents and Their Associated Waste Hanagement Pacilities, USALC Rep. ORNI-4451 (1970).

33. BLOWEKE, J. 0., Plant Siting Studies, presented at Annuai Neeting of the Chemical Technology Division at ORNL (1969). 


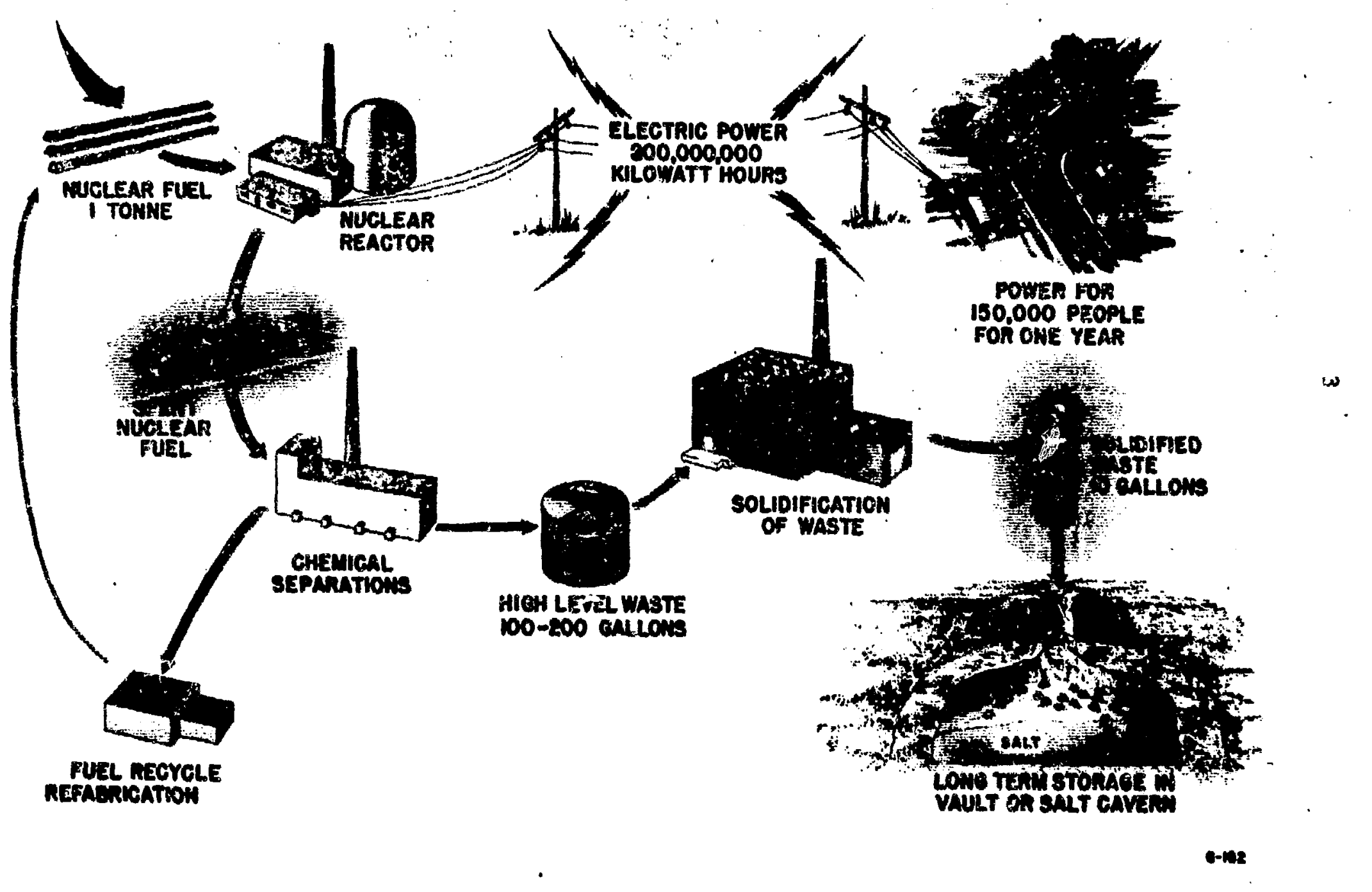

Figare 1

Hith Level Wastes in the Nuclone. Fued Cycile 


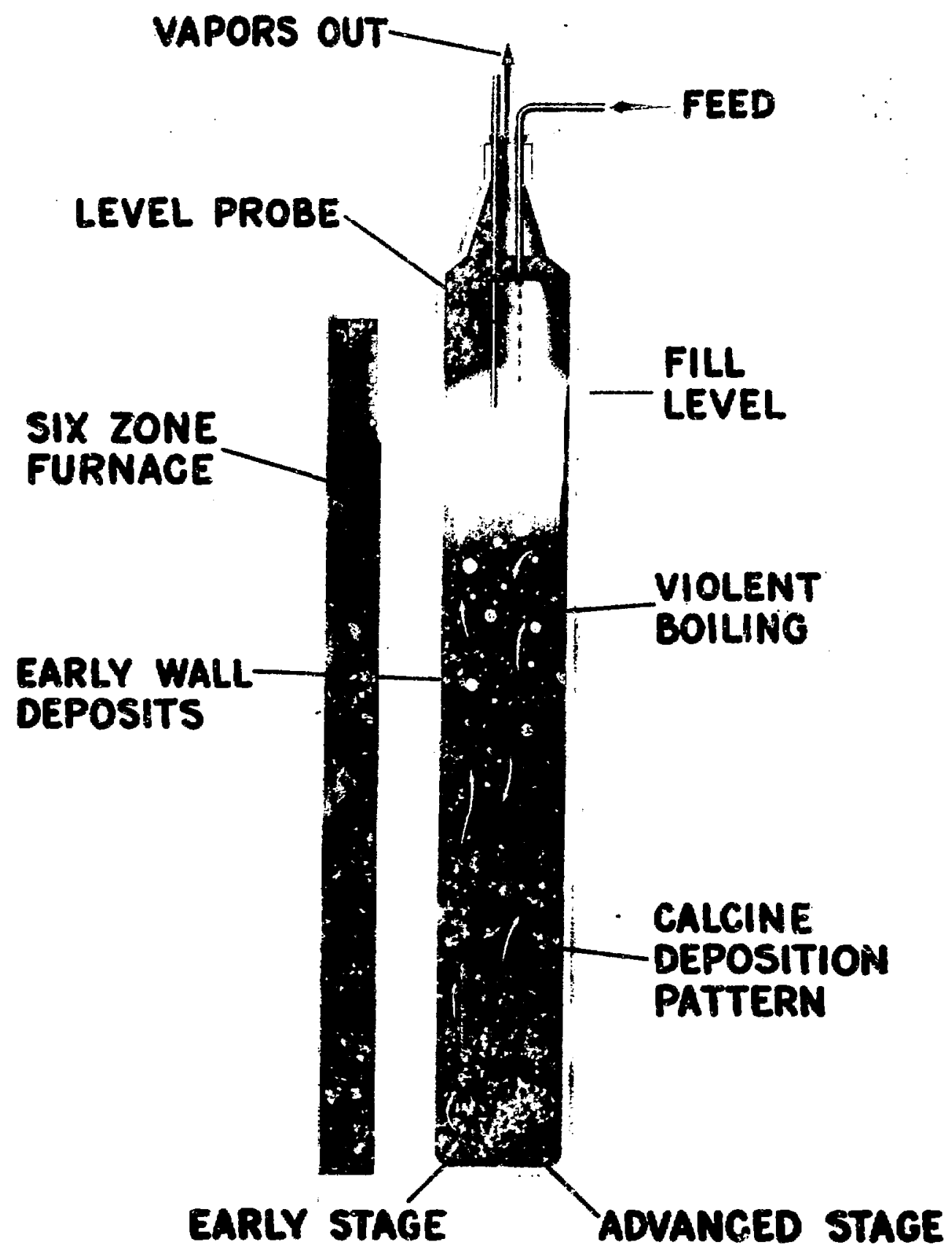

Prgure $2 \mathrm{a}$.

Fot Celedintion Procoss 

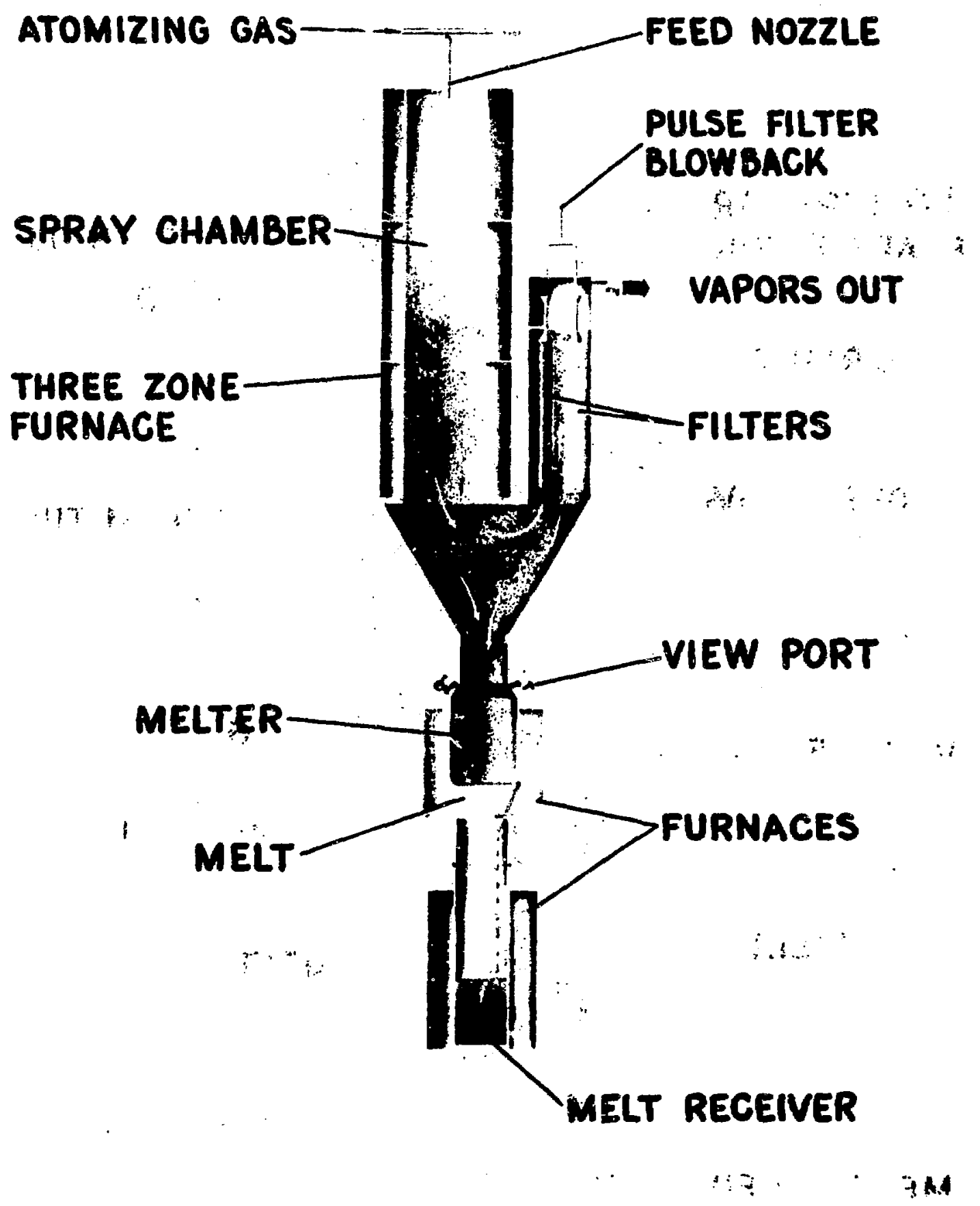


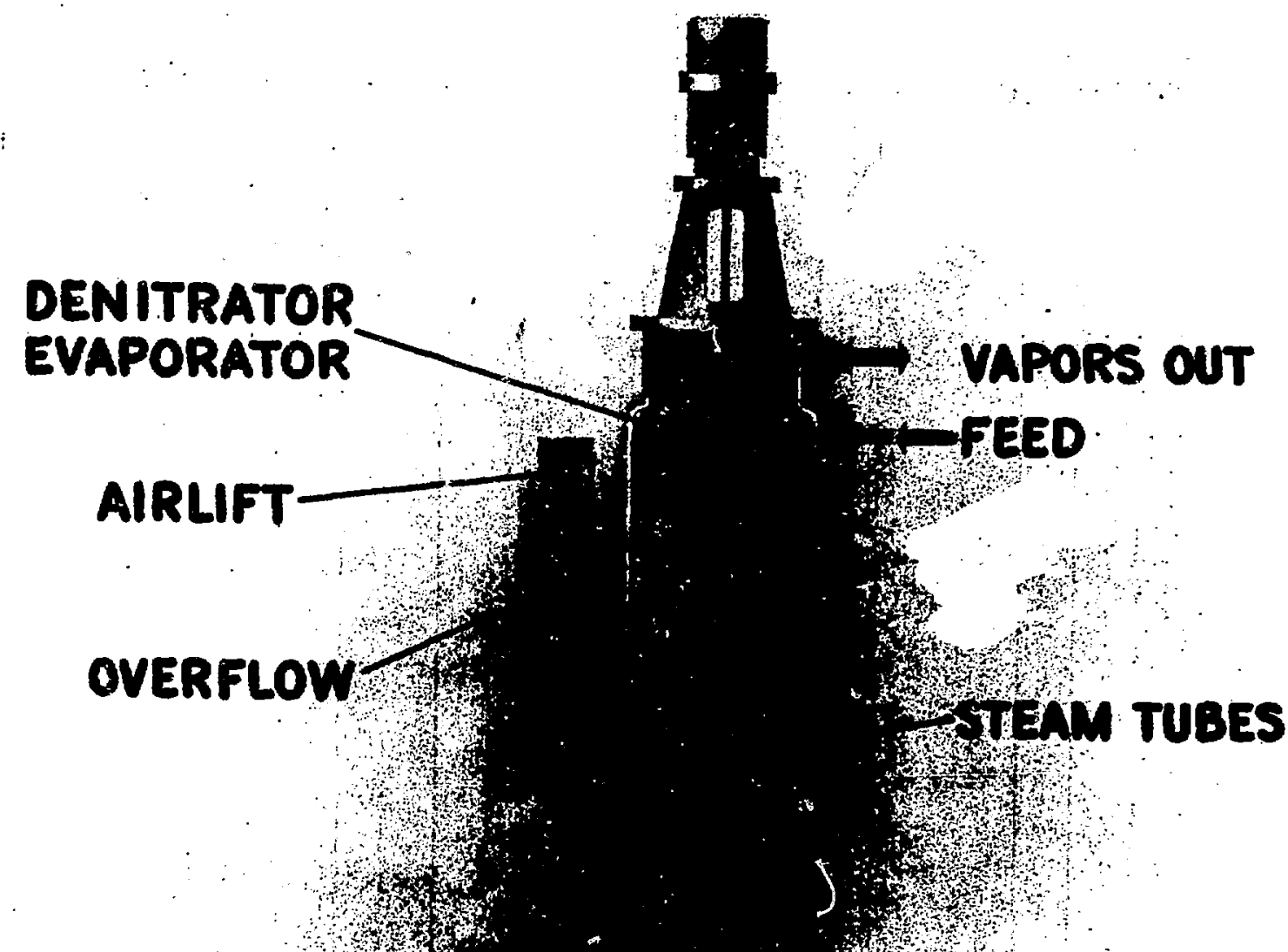

\section{VAPORS OUTH-x:}

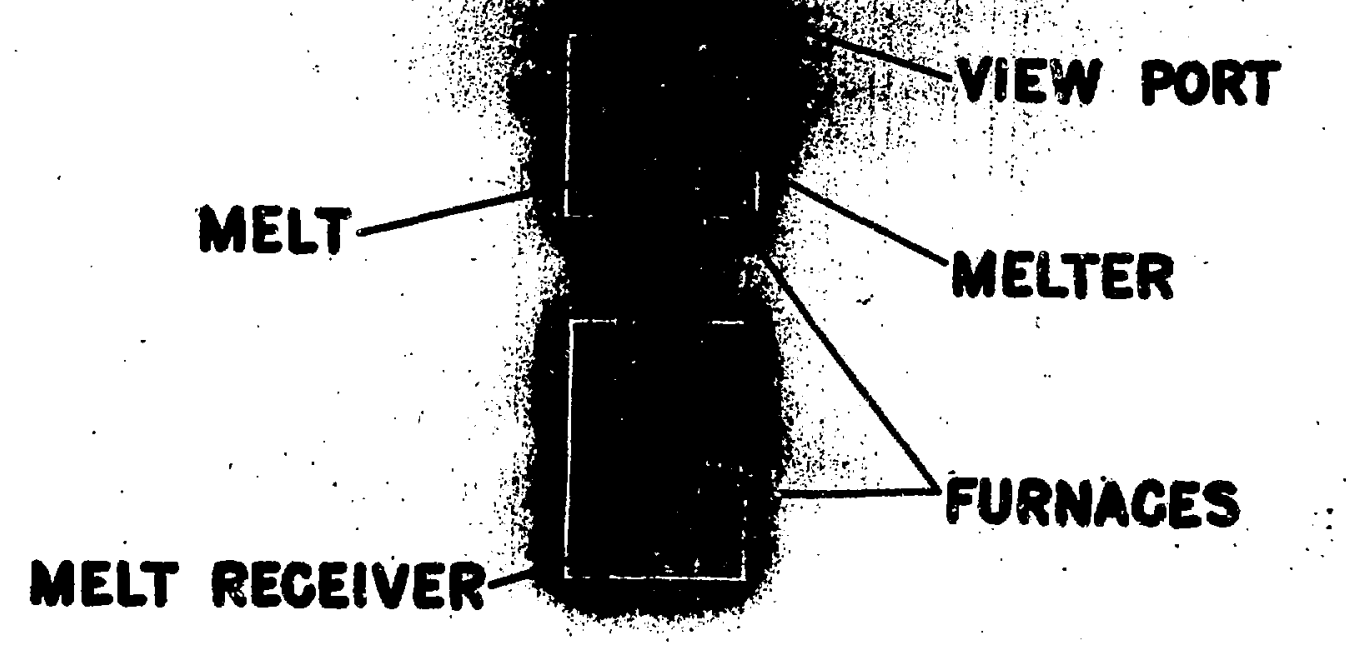

Figure 2e

Phosphate Glass Solldification Procens 


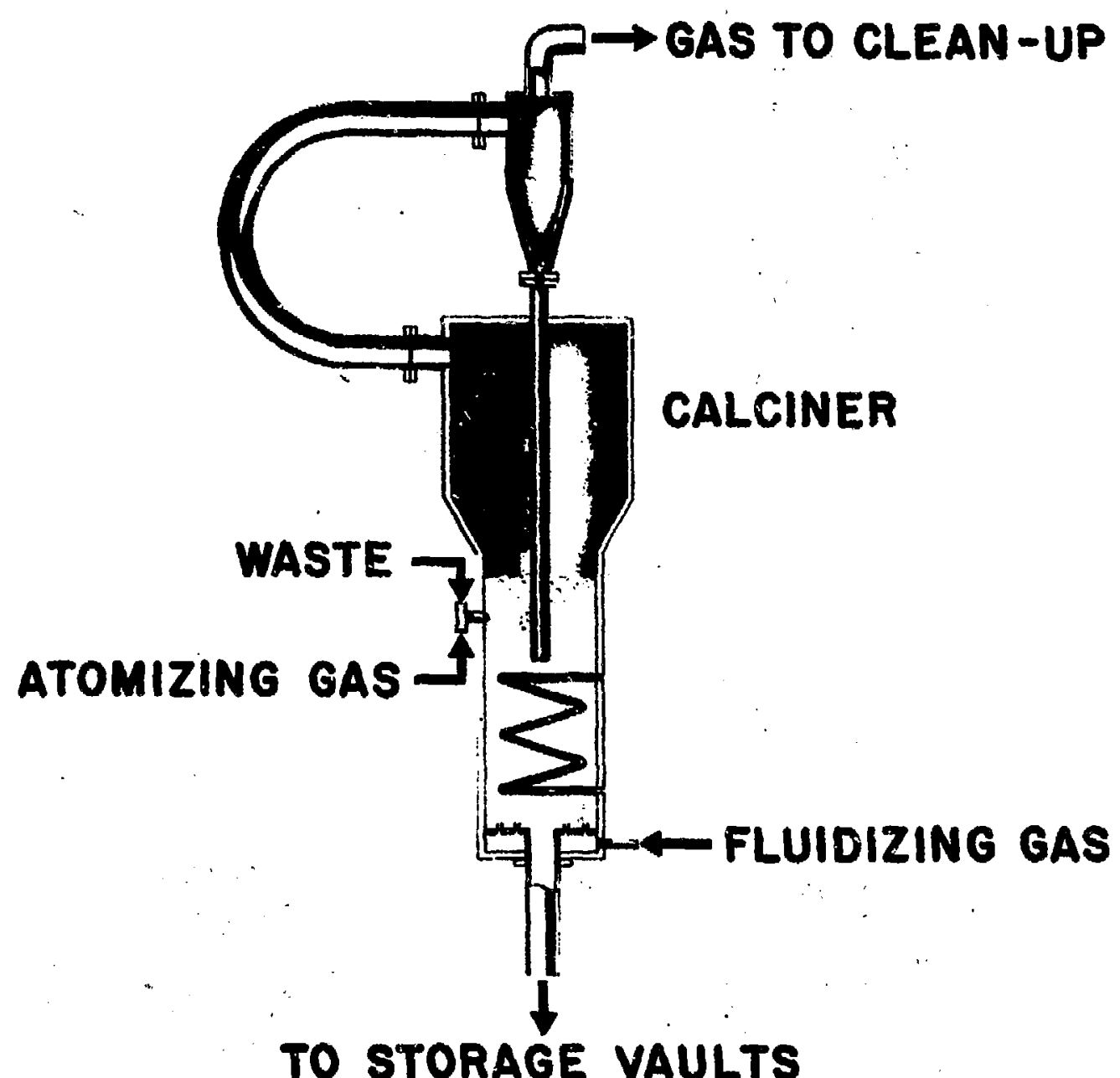

IIsure 28

Fuidsed sad Caloination Frosess 

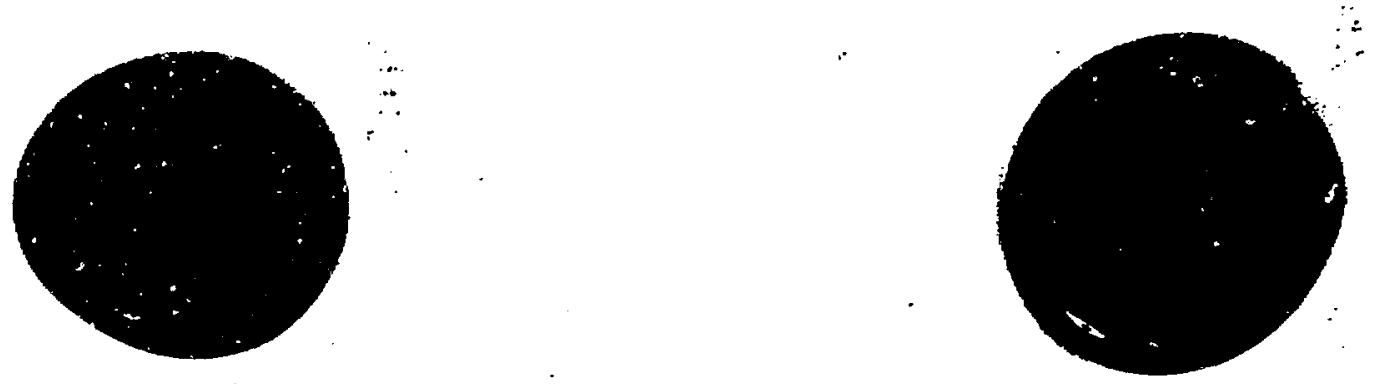

Spray Solidification

Phosphate Glass

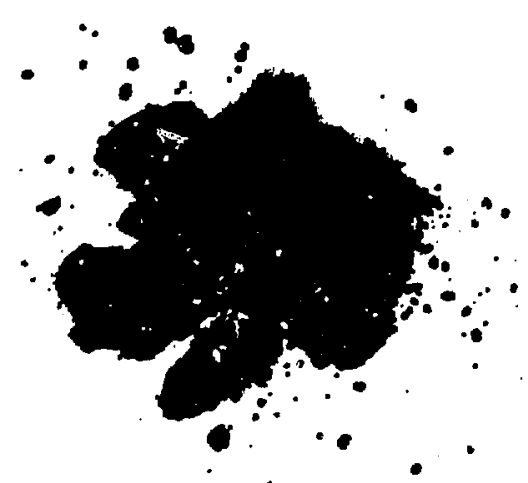

Pot Calcination

Fluidized Bed Calcination 
OnML-OWo ce-7iso

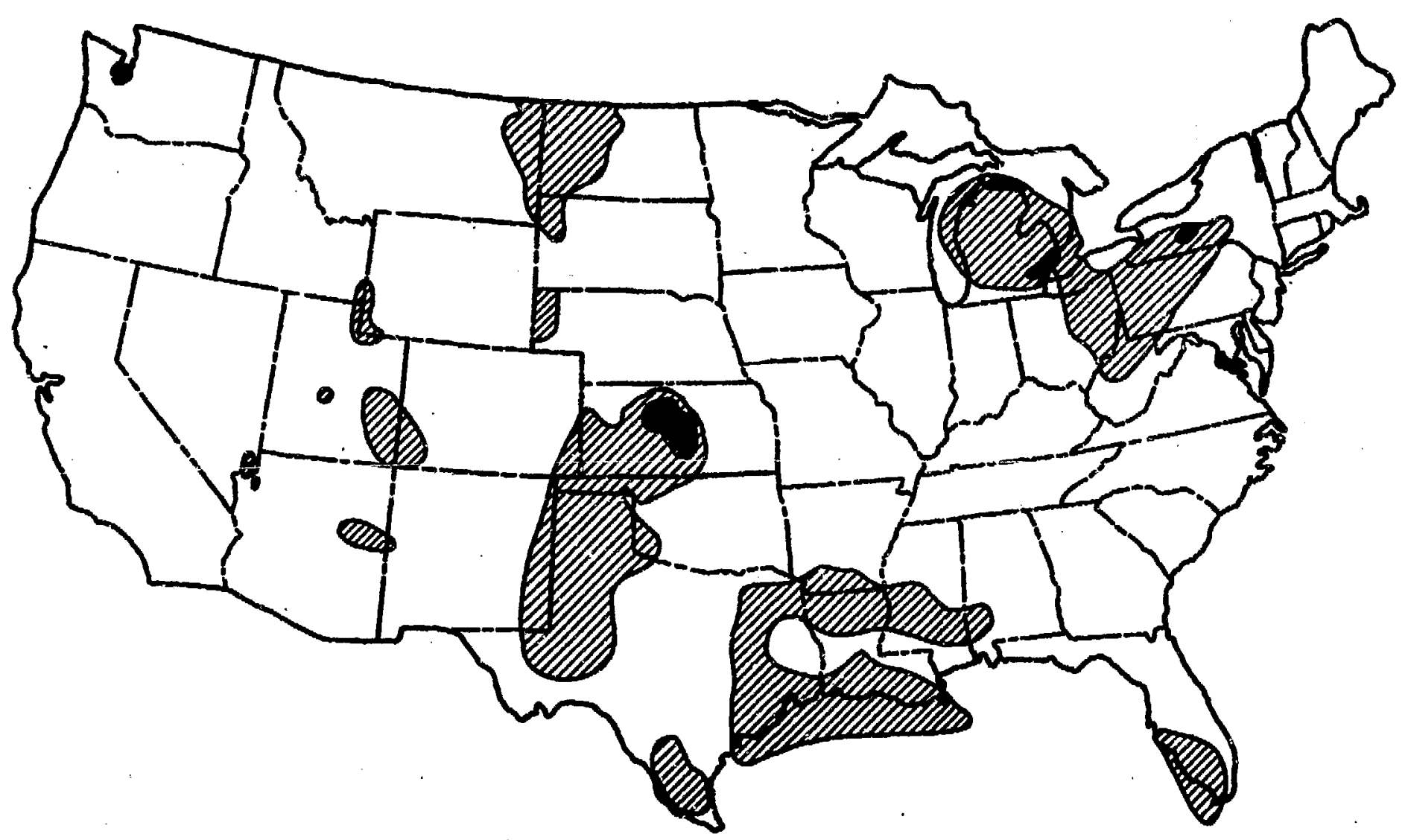

VIIIS ROCK SULT DEPOSITS IN THE UWITED STATES (AFTER PIERCE ANO RICH, U.S.G.S. BULL. 114O)

SALT DEPOSITS HAVINO THICKMESS OF AT LEAST $200 \mathrm{IH}$ AND LYIMO WITHIN $2000 \mathrm{H}$ OF LANO SURFACE.

Figure 4

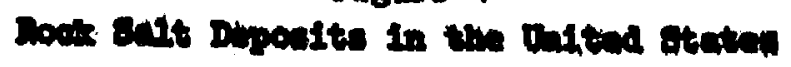




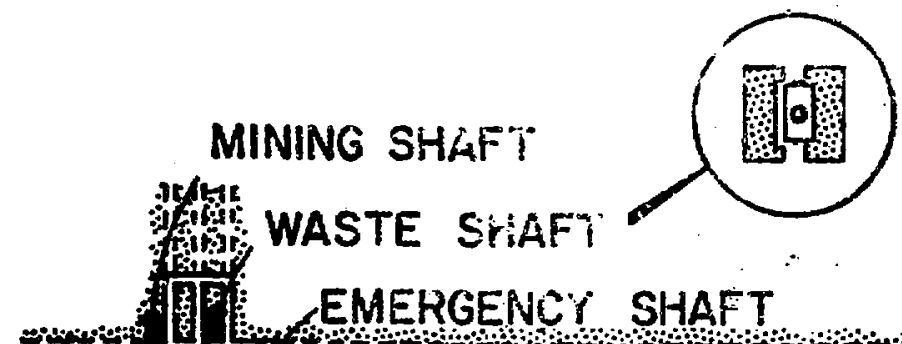

ORNL-DWG 64-3902R

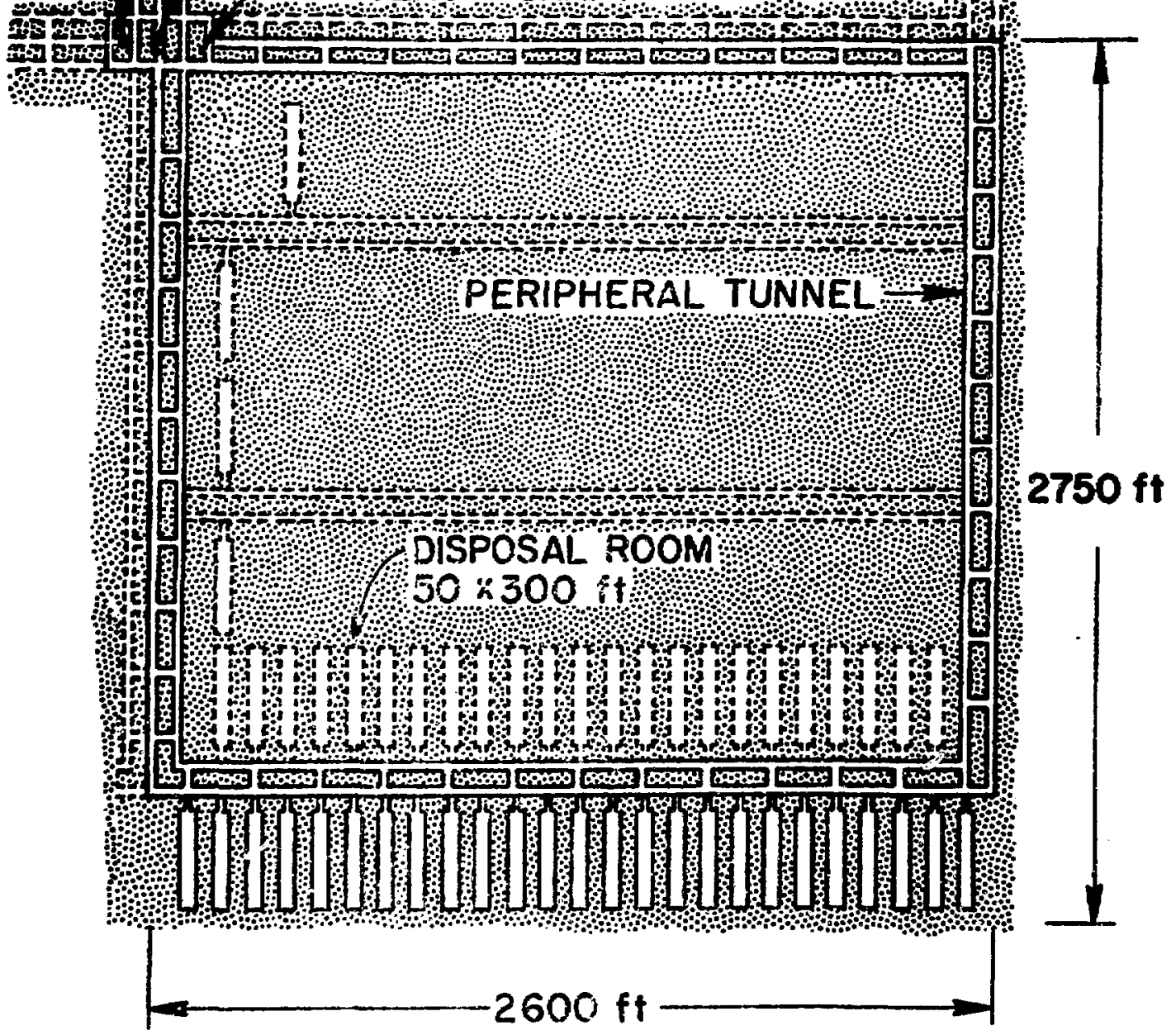

Figure 5

One Sector of lenceptual Vaste Disposel Mine 
NTERNATIONAL ATOMIC ENERGY AGENCY

in co-operation with

THE UNITED STATES ATOMIC ENERGY COMMISSION

SYMPOSIUM ON ENVIRONMENTAL ASPECTS

OF NUCLEAR POWER STATIONS

New York, 10-14 August 1970

ERRATA TO

$\operatorname{Sin}-146 / 23$

STATUS OF SOLTDIFICAMION AMT DISPOSAI OF

प्TTGATY RADJOACTIVE LTQUTD HASTES FROW NTCIAAR POWFR

WN TIT TSA

D.J Schnejdor

Rt Bredshas

AG Blasewits

Jo Blomeke

we Me clain
Batteljo-lorthweat, Richj and Washington

Oak Ridpe National Laboratory, Oak Ridge, Tennasene Battel Jo-Northwest, Richl and Washington

Oaj Ridge Hational Laboratory, Oak Ridge, Tennessee Oek Ridge National Laboratory, Oak Ridge, Tennessee

Based on Work Performed for the

Injtad States Atonic Bnergy Commission 


\section{ABSTRACI}

Solidification of highly radioactive liquid westes. frcm reprocessing of spent nuclear fuels vill soon be required ir the visA for additional Improvenent in safety during interim storage, during transportatica to finsl disposal, and during finel disposal at e Federal recository. Thering the past 15 yeers, major research and developsent hes been carried out to develop four basic processes for converting the high level liutuld sastes to encapsulated solids. These processes are: smray solidification, pot calcinetion, phosplinte glass solidification, and fluidized bed calcination. All processes are bcing demonstrated on an engineerine-scalc with ralioactive wastes. In all fowr processes, the waste is heated to $400{ }^{\circ} \mathrm{C}$ to $1200^{\circ} \mathrm{C}$ to drive off essentiaily all of the volatile constituents, lesving a solid or a meit that will cool to a solid.

Disposal of these radioactive wates requires irolation from the biological environment fur hundreds of thousands of jears. The longerity of the hazard implies that the disposal system should be capalule of providinc this isolation without surveillance. After considerable stuly, natural salt deposits were concluded to be the most gromisine diaposel locations in the USA for neeting these criteria. A coscegt for e facility to dispose of containers of solfdified highly radioactive waste in a salt mine has been investigated in an experjment in a salt mine. The overall disposal concept, as well as equipnent requirements and hnuding techniques, vere demonstrated.

The US-ABC has proposed that all solidified highly radiaactive waste frow nuclear power fuels be shipped to Federally owned repositorics. Studies are currently in progress on the detailnd desien and cost estimates for such a first demonstration disposel fecility to be located in a salt wine in the central area of the USA.

The cost of high level waste maregement involving solidification in combinations with interim liquid stcrage, interim soijd storage, transportation to final disposal, and disposal in a salt wine has been estimated to be about 37 to $45 \mathrm{milla} / \mathrm{MH} \mathrm{hr}$, or only slightly hiener than the cost range for perpetual Ilquid storage. 
FIHAL DISFOSAL II SALE

An ideal schenc for disposal of highly rafiokctive wastes is considered to be one which provides for conplete isolation and absence or interaction of the waste fran man's biosphere for time periods on the order of several hundred thousand years with no operation, seintenance, or survefllance required after disposal, and at an economical cost. [?]

Storage of wastes as liquids in neir-surface tanks has been a successful mears for contafning the radiouctive. wastes to date. Such storage is considured to be triporary only, because the waste is conteined in a mobile form within our biosphere, the tanks must te periodically replaced due to corrosion failure, and continual opretation and survelliance are required.

Othei disposal alternatives which have been investlgatsa in the Research and Development progratis sponfored by the US Atomic Enerky Commiasion are: (1) aisposal as solids in surface or near-surface vaults; 2.2 (2) disposal as liquids or slurries in caverns in deep geologic formatjons; $[23\}$ (3) disposal as solids in caverns in deep geologlc formations. [2h]

DHsposa? of wastes as solids in surfuce or near-surface vaults on comercial reproccssing plant sites appears acceptable for interin storage. However, for the very long term, surface dispocal or solids is considered -to be less desirable thau disposel in selectea deep geolofic formations because of the requirement of continued survelilance.

Safety considerations militate against the buik shipaent of high-lerel vaste liquids or slurries. Consequently, storage of these vastes in deep geologic formations vould require suitable feohydrologic conditions at the fuel reprocessing site, thus limitint the number and location of sultable reprocessing plant sites. Disposal of high level waste liquids or slurries in deep under Bround formations has not been cvaluated economically or technically for power reactor fuel reprocessing waste. However, the need to expend millions of dollars to determine whether any selected geologic formation is positively suitable for such an application would appear to limit this concept. While this concept cannot, at the present time, be conclusively eliminated elther on the basis of safety or ccononics, it is not expected to be an importent corcept in the nucleer power econory.

Disposal of higi:-level waste as solids in selected deep geologic formations appears acceptable fron joth the safety and economic standpoints. The initial stimilus for this part oi the AEC effluent control RED progran comenced In Sentember 1955, when, at the request of the Atomic Enerey Comission, a combittec of geologists and feophysicizte was established by the liational Acalenty of Sciences-?istional Research Council to study tive possibilities of disposine of high-level radioantive waste waterials ar land, and to indicate what research was needed to detcraine the reusibility! 


\section{ESTIUATED COSIS}

A number of cost estinate studies have been rade by bloneke and com vorkers at ORHL. These studies have investignted tlie totsi costs of manacing high level wastes, which inslude inierin liquid storare, conrersion to solids by pot calcination, interin sclids storage at the ruel reprocessing plent, trunsportation of solid to alt raine, and handling and burfal of the solid weste in a salt mine. A sufinary of these cost estinates is presented in Table 2. For the cases examined, costs for total waste management are estjmated tc be in the range of 37 to $45 \mathrm{mills} / \mathrm{MH} \mathrm{hr}$, or $\$ 9500$ to $\$ 12,000$ yer metric ton of fuel procassed. These costs reprcscnt approximately $1 \%$ of the total cost of nuclear power and approximately $10 \%$ of the total cost of reprocessing spent nuclear ruels. Comparable costs for perpetual storafe as liquids raxy from 30 to $35 \mathrm{milis}$ hat hre, or near the lower end of the range for storage as solids: 


\section{SUIASART}

Solidification represents the only practicel and reasonably attainable techrique for achieving a substantial incrense in the sarety essociated with the storing and disposal of the high level waste from the nuelear power industry. The use of this techrique is expected to soon become a policy of the US Atomic linergy Commission, wherein the soljdification of. highly radicactive liquid wastes will. be required before shiynent to a loag-term federal disposal site.

Mafor ADC-sponsored research and development on processes for converting the high-level liquid mestes to encapsulated solids is nearly completed. From these studies, four tasic solidification processes which are essentialy ready for commercial application have evolved.

After considerable engincering and experimentel study, mired caverns in natural salt deposits were concluded to be the most promisinf locations to provide the isolation required for hundreds of thousands of years. Studies are currently being unade on the details of a Federal denonstration disposal facility in a salt mine in central USA.

The cost of inith-ievel waste management involving solidification in continntions with interim liquid storage, interin soljd storage, and transportation to final disposal at a salt mine has been estinated to be - in the range of 37 to $45 \mathrm{mills} / \mathrm{MW} / \mathrm{Hr}_{\mathrm{e}}$, or only slightly higher than the cost range for perpetual liquid storage. 